\title{
Role of Zakat as Social Finance Catalyst to Islamic Banking and Economic Growth
}

\author{
Ai Nur Bayinah \\ STEI SEBI
}

\begin{abstract}
This paper is aimed to assess the contribution of Zakat in boosting Islamic banks' financing and economic growth for the period 2011-2015, in 10 district/city of West Java Province, Indonesia. Through Vector Autoregressive (VAR) panel co-integration analysis, variance decompositions (VD) and impulse response functions (IRF), this study investigates Zakat, Islamic Banking, and economic growth nexus. Findings in this research highlight that Zakat has a significant impact on Islamic banking, so this institution would contribute to economic growth both in the short and the long run, with fluctuation in variance from the first year. The results lend support to the view that Zakat not only leads to social benefits but also has a positive impact on the economy through increasing Islamic banks' financing. Therefore, this research will serve as a motivation for the industry players and regulators to continuously promote Zakat as a strategic policy. The originality of this research is to assess Zakat-led growth and finance by analyzing the impact of Zakat on the Islamic banking and regional economic outcome. Another novel aspect of this study is in the methodology as it employs $V A R$ panel co-integration analysis, VDs and IRFs on the set of annual data.
\end{abstract}

Keywords: Zakat, Islamic Banking Financing, Economic Growth, West Java

\section{INTRODUCTION}

Theoretically, in the classical and modern literature, Zakat collection is always seen as the responsibility of government. Zakat is an effective tool to realize the purpose of fiscal goals that are expected to affect the state of development (Ramadhan, 2017; Jasafat, 2015), as well as social welfare of society, as listed in Al-Amwal by al-Dawudi, which is similar to Rawls's theory of social justice (Dasuki, 2015).

Islamic money and property management bridges the gap between the rich and the poor. Zakat enhances the circulation of wealth and ensures that wealth does not remain idle and hoarded. Nonetheless, seeing from the macroeconomic perspective, Zakat is used to increase the aggregate demand due to mustahik's high spending. Thus, it will boost economic growth and will encourage investment. It is also an instrument of fiscal policy that serves to ensure that economic activity can run at the level of primary needs fulfillment (Siddiqui, 2005).

Therefore, the governments of Muslim countries need to give serious attention to optimize Zakat as a source of growth and equitable distribution of wealth. There is a need for a concerted step from the government and society to do the reconstruction of the spirit of Zakat, to prevent lack of focus as happened in past (Faisal, 2011). Consequently, a deficit of truth will occur as described in Lieven Boeve theory (Boeve, 2003).

The revitalization and implementation of Zakat in various Muslim countries, including Indonesia, is often seen as part of the identity politics (Kuran, 1997). Although for Neinhaus 
(1988), Chapra (1992), and Presley and Sessions (1994), it is a tangible form of economic development and welfare improvement apparatus based on the Islamic paradigm (Susanto \& Cahyadin, 2008). Despite the fact that to create sustainable development that has political, social, ethical, and moral complexity, the multi-dimensional problems cannot be solved by economic approach alone (Hasan, 2006).

The research by Hassan and Khan (2007) shows that Zakat funds can increase the government's tax potential through increasing productivity, employment and production, and can replace the government's expenditure budget by $21 \%$ of the Annual Development Program (ADP) in 1983 / 1984 and up to $43 \%$ in 2004/2005 in Bangladesh. So the government can use it for other development and social expenditures. However, the government does not see the need to include Zakat as an instrument of government policy and take Zakat institution as part of the national strategy.

In regards to the relationship between Zakat and purchasing power, Kahf (1999) explains that the payment of Zakat by groups that have more financial capability also known as muzakki is distributable to increase the purchasing power of the eligible (mustahik). The increase in purchasing power then increases the demand for commodities and then with the number of more commodities, the price will be cheaper and will be stable.

The research which was done by Suprayitno et al. (2013) in Malaysian Peninsula shows that Zakat distribution has a positive impact towards aggregate consumption. Besides, this research recommends to not limit Zakat distribution only to consumer needs, but also to financial needs that will result in sustainable income to the eligible. Similar to the recommendation of Bremer (2013), Zakat mobilization in long-term is more powerful to encourage growth, as is also confirmed by the research of Mahat \& Warokka (2013) in 19 Muslim countries by taking the data for the period 20042010 .

In Islam, donations play an important role in both classical (Al-Haritsi, 2006) and modern (Shiddiqi, 2005) economics, but conventionally (Keynes, 2003), the theory of economic growth is largely void of the discourse. The linkage of both is the crucial problem of income distribution, which according to neoclassical occupies a secondary place and is assumed to be governed by marginal productivity. Such as the determination of wages for various jobs determined by the pure market forces of supply and demand. But the mechanical model of wage determination and income distribution does not hold up in a world where monopsony features, imperfect competition and economic and social forces come into play. In a world like this, unlike the ideal world of market fundamentalism, market power does not yield optimal results and there is room to modify the distribution of income. Thus, policy-oriented frameworks for analyzing the relationship between distribution and growth needs to be done with other approaches besides pro-labor and procapital distribution policies (Lavoie \& Stockhammer, 2012). In such cases, the instrument of Zakat is the answer.

As an effort to pair religious approach (Freundenberg, 2011) which is elastic and flexible (Ghadi, 1994) with the conventional approach, the majority uses the approach of maximizing social welfare and social welfare approach which was undertaken by Edgeworth, Ramsey, Pigou, and Samuelson before 1955. Furthermore, optimal taxation approach examined by Mirless and Atkinskon is also used. Finally, the often used approach for public decision making, i.e. pareto optimality approach (Winer \& Hettich, 20004) is also used by adding government intervention 
(Kantakji, 2008) to optimize its formulation (Nahi, 1994).

Zakat-related research has actually been largely done both normatively (Kahf, 1997; Misanam \& dkk, 2008) as well as empirically as in Malaysia (Yussof, 2011) and Pakistan (Azam, Iqbal, \& Tayyab, 2014). So, in general, there are at least four possible approaches that can explain the causal relationship between Zakat and economic growth, namely: (1) Zakat is a determinant of economic growth (Zakatled growth hypothesis) or so-called "supply-leading view", (2) Zakat follows the economic growth (growth-led Zakat hypothesis), or so-called "demandfollowing view", (3) the mutual relationship between Zakat and growth (bidirectional causality view), and (4) the independent hypothesis that Zakat and growth are interconnected.

In relation to the implementation of Zakat in Indonesia specifically, there has not been any research to include the element of Zakat as a determinant of economic growth, especially regionally, such as the research in South Sulawesi (Afrizal, 2013), Bali (Jaya \& Dwirandra, 2014), Aceh (Darwanis \& Syukriy, 2013) and West Java (Sularno, 2013). The reviews are more normative (Mustafa, 2014), and mainly in poverty alleviation studies (Ariyani, 2016).

The implementation of Zakat in West Java will be an important starting point for the implementation of Zakat in regional policy. Zakat decentralization is a key factor to solve the problems that plague the Muslim community in the region. A system is needed to be used in the distribution of Zakat fund (Rosadi \& Athoillah, 2015). According to Mth (2003), the role of Zakat is not only for the local community, but may be distributed to various regions if the community's needs are fulfilled. However, he regretted that a study examining the application of Zakat's influence in the economic development process is almost non-existent, as also affirmed by Shiddiqi (2005).
Consequently, the purpose of this study is primarily aimed at that and specifically to try to: (1) Identify the pattern of relationship between Zakat, the financing of Islamic Banking and economic growth; (2) Analyze the financing and economic growth on shocks that occur in Zakat. Thus, it is expected to provide benefits especially to (1) regulators in encouraging the receipt of Zakat and then incorporating it as an important instrument in the public policy it releases; (2) for the Islamic Finance industry to enhance the optimization of Zakat as a potential source of funding; And also for (3) scientific development, especially in conducting empirical studies related to the role of Zakat as one of the determinants of economic growth and Islamic financing in Indonesia.

\section{RESEARCH METHODOLOGY}

The study used data from Zakat institutions, Islamic bank's financing assets, and economic growth from 10 district/cities in West Java during 20112015. Data is obtained from the Central Bureau of Statistics of West Java (BPS, 2016; 2015; 2014; 2013; BPS, 2012) and Shari'ah Banking Statistics from Central Bank of Indonesia (Bank Indonesia, 2011; 2012; 2013; 2014; OJK, 2015).

The variables used are Zakat receipts collected by West Java Regional Office of Religious Affairs, Islamic bank's financing as a representation of commercial finance indicators, and Gross Regional Domestic Product (GRDP) as a representation of the economic growth.

\section{Model and Research Methods}

The purpose of the model used in this research is to assess the contribution of West Java's Zakat receipts on financing and regional economic growth, which is:

Fin $_{t}=\beta 1+\beta 2 Z_{t}+\varepsilon_{t}$

$P D R B_{t}=\beta 1+\beta 2 Z_{t}+\beta 3$ Fin $_{t}+\varepsilon_{t}(2)$ 
VAR is used when there is a theoretical relation between variables, which are tested by stationarity on differentiated and the nonintegrated data (Gujarati, 2004). This research was done with Eviews 9.

\section{Unit Root Test}

The stationarity test is performed so that the data used can yield reliable estimation of econometric models. This does not happen if the data is not stationary because it contains the root of the unit and tends to fluctuate not around the average.

Its condition will complicate estimation and produce regression models that have high determinant coefficient values, $\mathrm{R}^{2}$, and significant $\mathrm{t}$ statistics, but theoretically it has no significant relationship. For that, Augmented DickeyFuller test (ADF test) is used as taken from the name of the inventor, Dickey Fuller (1979) and Phillips-Perron test (PP test) as the inventor, Phillips Perron (1988). As shown in the model below:

$$
\Delta Y_{t}=\beta 1+\beta 2_{t}+\delta \beta_{t-1}+\varepsilon_{t}
$$

Parameter used is $\beta 1$ and $\beta 2_{t}$, with t shows variable time and trend, while $\delta$ explains drift and finally, $\varepsilon_{t}$ is the white noise error term. If the null hypothesis $\left(\mathrm{H}_{0}\right)$ shows $\delta=0$, it means that there is presence of unit root. Therefore, the data series is not stationary. Meanwhile if the alternative hypothesis is $\delta<0$, then the data series is stationary. Besides, if the statistical result of ADF is above MacKinnon critical values, then $\mathrm{H}_{0}$ hypothesis is rejected, which means that the data is stationary.

However, the non-stationary data series can be transformed to stationary data with the differentiation process on the first level. The differentiation could be stated as follows:

$$
\Delta 2 Y_{t}=\beta 1+\beta 2 \Delta Y_{t-1}+\varepsilon_{t}
$$

Philips Perron (PP) test is focused on serial correlation and heteroskedasticity of the error term and hence it is different from the ADF test. If the result of the null hypothesis $\left(\mathrm{H}_{0}\right)$ is $\lambda=0$, it means that $\mathrm{Z}$ is non-stationary. Conversely, if the alternative hypothesis is found to be valid, then it means that the data is stationary. The model of PP test could be presented as follows:

$$
\begin{aligned}
& \Delta \mathrm{Zt}= \pm \theta \mathrm{t}+\lambda \mathrm{t}-1+\mu \mathrm{t} \\
& \Delta Z_{t}= \pm \theta_{t}+\pi_{t-1}+\mu_{t}
\end{aligned}
$$

\section{Johansen Co-integration Test}

Data could be mutually cointegrated and have long-term relationships if the combination of two non-stationary series move in the same direction toward its long-run equilibrium and the differentiation between the two data is constant.

The purpose of this test is to empirically discover the long-term relationship of Zakat with increasing purchasing power and economic growth of Aceh.

Integration test between Zakat, increasing purchasing power and economic growth is based on Johansen's Vector Autocorrelation Regression (VAR) approach. If $\mathrm{Yt}$ is a vector of endogenous variables in VAR with lag length $p$, then:

$$
\begin{gathered}
\mathrm{Yt}=\Phi 1 \mathrm{Yt}-1+\Phi 2 \mathrm{Yt}-2+\ldots+ \\
\Phi l \mathrm{t}-\mathrm{l}+\beta \mathrm{Xt}+\eta \mathrm{t}, \mathrm{t}=1, \ldots ., \mathrm{T},
\end{gathered}
$$

$$
\begin{aligned}
& \text { Explanation: } \\
& \mathrm{Wt} \quad=\text { endogenous variable vector } \\
& \Phi \mathrm{l} \quad=\text { matrix parameters } \\
& \beta \mathrm{Xt} \quad=\text { d-vector of deterministic variable } \\
& \eta \mathrm{t} \quad=\text { innovations vector }
\end{aligned}
$$

This VAR specification can be presented in first difference with no co integrated relationship between variables. As in the model: 
$\Delta \mathrm{Yt}=\Gamma 1 \Delta \mathrm{Yt}-1+\Gamma 2 \Delta \mathrm{Yt}-2+\ldots+\Gamma \mathrm{l}-$

$1 \Delta \mathrm{Yt}-\mathrm{l}+1+\Pi \mathrm{Yt}-\mathrm{l}+\beta \mathrm{Xt}+\eta \mathrm{t}, \mathrm{t}=1, \ldots, \mathrm{T}(7)$

Explanation:

$\Gamma \quad=$ estimated parameters

$\Delta \quad=$ difference operator

$\Pi \quad=$ long-term matrix parameters

The number of co-integration vector obtained from the signification of $\Gamma$ through two tests of likelihood test:

1. Maximum eigen value: $\lambda \max =-\mathrm{T}$ $\ln (1-\lambda r+1)$

2. Trace statistic: $\lambda$ trace $=-\mathrm{T} \Sigma \ln$ $(1-r+1)$

$\lambda=$ estimated value of eigenvalue obtained from estimated values on $\Gamma$

$\mathrm{T}=$ number of observations

\section{Granger Causality}

As an effort to investigate the relationship between Zakat, purchasing power and economic growth, Granger Causality is used to test a mutual relationship. As in the model:

$$
\begin{gathered}
\Delta \mathrm{Y}_{1 \mathrm{t}}=\mu_{1}+\gamma_{11}(\mathrm{~L}) \Delta 1_{\mathrm{t}-1}+\gamma 1_{2}(\mathrm{~L}) \\
\Delta \mathrm{X}_{2 \mathrm{t}-1} \pm 1\left(\beta^{\prime} \mathrm{X}_{\mathrm{t}-1}\right)+\varepsilon_{1 \mathrm{t}} \quad(10) \\
\Delta \mathrm{Y}_{2 \mathrm{t}}=\mu_{2}+\gamma_{21}(\mathrm{~L}) \Delta 1_{\mathrm{t}-1}+\gamma_{22}(\mathrm{~L}) \\
\Delta \mathrm{X}_{2 \mathrm{t}-1} \pm 2\left(\beta^{\prime} \mathrm{X}_{\mathrm{t}-1}\right)+\varepsilon_{2 \mathrm{t}}
\end{gathered}
$$

Explanation:

$\mu_{1}$ and $\mu_{2} \quad=$ constant, a drift of $\Gamma \mathrm{ij}$

$\beta^{\prime}=$ stationary linear combination of $Y 1_{t-1}$ and $Y 2_{t-1}$

\section{Impulse-Response Function (IRF) and} Variance Decompositions (VD) Analysis

This study uses IRF and VD to analyze dynamic relationships among variables of Zakat, financing and economic growth of West Java. IRF describes the response of an endogenous variable to the shock of a particular variable and that how long is its influence. However, VD would be given a percentage of variable variation which is explained by other variables. As an effort to measure the contribution of Zakat to increase financing and economic growth of this region and the implications of its response, VD and IRF are used.

\section{RESULTS \& DISCUSSION}

Since the most important purpose in Islamic economics is ensuring stability and economic growth, other purposes such as fulfilling the basic needs, equality of opportunity, distribution and welfare improvements must also be met (Shiddiqi, 2005, pp. 6-7). Therefore, this research is important to do the vital step to prove and make a decision about those purposes. Anyway, before performing the VAR test stages, an Ordinary Least Square (OLS) test of the data is performed, wherein the results explain that the data can be used for further analysis according to VAR criteria.

Table 1. Result of Ordinary Least Square Test

\begin{tabular}{|l|l|l|l|}
\hline \multicolumn{1}{|c|}{ OLS Test } & \multicolumn{1}{c|}{ Indicator } & \multicolumn{1}{c|}{ Result } & \multicolumn{1}{c|}{ Explanation } \\
\hline Multicollinearity & \multicolumn{1}{c|}{ More than 0.8} & Less than 0.8 & No multicollinearity. \\
\hline Heteroscedasticity & P-value more than 0.05 & More than 0.05 & No heteroscedasticity. \\
\hline Autocorrelation & P-value more than 0.05 & More than 0.05 & No autocorrelation. \\
\hline Normality & P-value more than 0.05 & More than 0.05 & Data are normally distributed. \\
\hline
\end{tabular}

Table 2. Result of ADF test

\begin{tabular}{|l|l|c|c|c|c|c|}
\hline \multicolumn{1}{|c|}{ Variables } & \multicolumn{1}{|c|}{ Unit Root } & $\begin{array}{c}\text { ADF Test } \\
\text { Statistic }\end{array}$ & $\begin{array}{c}\text { Critical } \\
\text { Value 5\% }\end{array}$ & $\begin{array}{c}\text { Levin T- } \\
\text { Statistic }\end{array}$ & $\begin{array}{c}\text { Critical } \\
\text { Value 5\% }\end{array}$ & $\begin{array}{c}\text { Stationary } \\
\text { Result }\end{array}$ \\
\hline Zakat & Level & 6.74157 & 0.9921 & -1.62330 & 0.0523 & Not Stationary \\
\hline & $1^{\text {st }}$ Difference & 19.3137 & 0.3727 & -6.50470 & 0.0000 & Stationary \\
\hline Financing & Level & 16.6129 & 0.6780 & -5.83591 & 0.0000 & Stationary \\
\hline
\end{tabular}




\begin{tabular}{|l|l|c|c|c|c|c|}
\hline & $1^{\text {st }}$ Difference & 32.2472 & 0.0000 & -10.3336 & 0.0000 & Stationary \\
\hline PDRB & Level & 0.21181 & 1.0000 & 16.0342 & 1.0000 & Not Stationary \\
\hline & $1^{\text {st }}$ Difference & 53.1181 & 0.0001 & -7.12334 & 0.0000 & Stationary \\
\hline
\end{tabular}

Table 3. Result of Optimal Lag Length Test

\begin{tabular}{ccccccc}
\hline \hline Lag & LogL & LR & FPE & AIC & SC & HQ \\
\hline \hline 1 & -529.2019 & NA & $1.89 e+22$ & 59.80021 & 60.24539 & 59.86159 \\
2 & -504.9241 & $32.37037^{*}$ & $3.72 e+21^{*}$ & 58.10268 & $58.99305^{\star}$ & $58.22545^{\star}$ \\
3 & -495.7929 & 9.131233 & $4.55 e+21$ & $58.08810^{*}$ & 59.42365 & 58.27225 \\
\hline \hline
\end{tabular}

* indicates lag order selected by the criterion.

LR: sequential modified LR test statistic (each test at $5 \%$ level).

FPE: Final prediction error.

AIC: Akaike information criterion.

SC: Schwarz information criterion.

$H Q$ : Hannan-Quinn information criterion.

Table 4. Granger Causality Test Result

\begin{tabular}{|c|c|c|c|c|}
\hline $\begin{array}{c}\text { Independent } \\
\text { Variable }\end{array}$ & $\begin{array}{c}\text { Dependent } \\
\text { Variable }\end{array}$ & Probability & Result & Explanation \\
\hline FIN & PDRB & 0.5435 & Not Reject $\mathrm{H}_{0}$ & IBF is not an independent variable of PDRB \\
\hline PDRB & FIN & 0.0059 & Reject $\mathrm{H}_{0}$ & PDRB is an independent variable of IBF \\
\hline ZAKAT & PDRB & 0.1997 & Not Reject $\mathrm{H}_{0}$ & Zakat is not an independent variable of PDRB \\
\hline PDRB & ZAKAT & 0.5107 & Not Reject $\mathrm{H}_{0}$ & PDRB is not an independent variable of Zakat \\
\hline ZAKAT & FIN & 0.0004 & Reject $\mathrm{H}_{0}$ & Zakat is an independent variable of IBF \\
\hline FIN & ZAKAT & 0.8744 & Not Reject $\mathrm{H}_{0}$ & IBF is not an independent variable of Zakat \\
\hline
\end{tabular}

If the ADF value is less than the critical value (5\%), then $\mathrm{H}_{\mathrm{o}}$ is rejected and it means that there is no unit root or stationary data. Moreover, some variables are not stationary at the levels, but are stationary after taking first differences (Table 2).

Determining the lag length is very important in the estimation because it can be used to eliminate the problem of autocorrelation in the system. The used criteria are Akaike Information Criterion (AIC), Schwarz Information Criterion (SC) or Hannan Quinin (HQ). The table shows that the optimal result is in the $4^{\text {th }}$ lag. However, by using VAR in Eviews 9, the maximum lag of 2 is used.
The Granger Causality test is performed to analyze whether endogenous variables can be defined as exogenous if their probability is less than 0.05 . It is used to inspect the relation of variables to each other. It examines that how much is the value of a variable in the current period is explained by other variables in the previous period. The results found that Zakat has a correlation with Islamic bank's financing (IBF).

VAR can be used if the model has no integration at the first difference. If there is no co-integration, the results in VAR are identical to Ordinary Least Square (OLS). Therefore, this test is a mandatory step.

Table 5. Co-integration Test Result

Unrestricted Co-integration Rank Test (Trace)

\begin{tabular}{ccccc}
\hline \hline $\begin{array}{c}\text { Hypothesized } \\
\text { No. of CE(s) }\end{array}$ & Eigenvalue & $\begin{array}{c}\text { Trace } \\
\text { Statistic }\end{array}$ & $\begin{array}{c}0.05 \\
\text { Critical Value }\end{array}$ & Prob. * $^{*}$ \\
\hline \hline None & 0.633866 & 21.21162 & 29.79707 & 0.3446 \\
At most 1 & 0.151725 & 3.126007 & 15.49471 & 0.9609 \\
At most 2 & 0.009075 & 0.164095 & 3.841466 & 0.6854
\end{tabular}




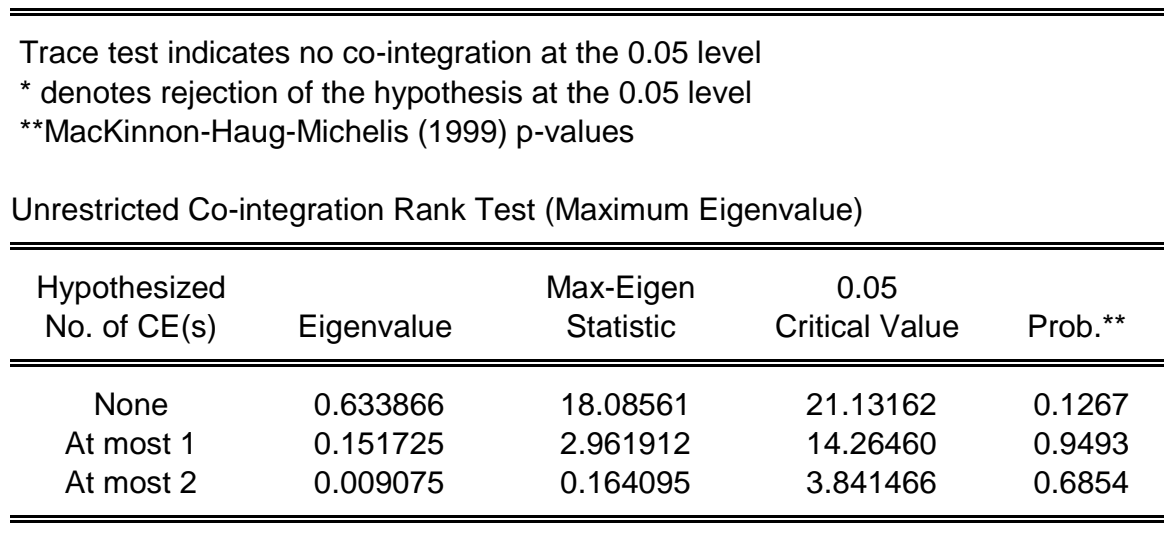

Max eigenvalue test indicates no co-integration at the 0.05 level

* denotes rejection of the hypothesis at the 0.05 level

${ }^{* *}$ MacKinnon-Haug-Michelis (1999) p-values

Unrestricted Co-integrating Coefficients (normalized by $b^{\prime *} S 11^{*} \mathrm{~b}=\mathrm{I}$ ):

\begin{tabular}{|c|c|c|c|}
\hline $\begin{array}{c}\text { PDRB } \\
0.000100 \\
-0.000411 \\
0.000171\end{array}$ & $\begin{array}{c}\text { FIN } \\
0.001516 \\
0.001649 \\
0.001558\end{array}$ & $\begin{array}{c}\text { ZAKAT } \\
0.000393 \\
-0.000231 \\
-0.000295\end{array}$ & \\
\hline \multicolumn{4}{|c|}{ Unrestricted Adjustment Coefficients (alpha): } \\
\hline $\begin{array}{c}\mathrm{D}(\mathrm{PDRB}) \\
\mathrm{D}(\mathrm{FIN}) \\
\mathrm{D}(\mathrm{ZAKAT})\end{array}$ & $\begin{array}{r}1.044784 \\
122.7825 \\
-143989.6\end{array}$ & $\begin{array}{r}6.010820 \\
-162.0081 \\
5408.441\end{array}$ & $\begin{array}{r}20.86841 \\
29.78336 \\
-4530.747\end{array}$ \\
\hline 1 Co-integratin & lation(s): & Log likelihood & -491.3278 \\
\hline
\end{tabular}

Normalized co-integrating coefficients (standard error in parentheses)

$\begin{array}{ccc}\text { PDRB } & \text { FIN } & \text { ZAKAT } \\ 1.000000 & 15.10452 & 3.918099 \\ & (6.39023) & (1.22330)\end{array}$

Adjustment coefficients (standard error in parentheses)

$\begin{array}{cc}\mathrm{D}(\mathrm{PDRB}) & 0.000105 \\ & (0.00697) \\ \mathrm{D}(\mathrm{FIN}) & 0.012322 \\ & (0.01678) \\ \mathrm{D}(\text { ZAKAT }) & -14.45069 \\ & (3.81241)\end{array}$

\begin{tabular}{lll}
\hline \hline 2 Co-integrating Equation(s): $\quad$ Log likelihood & -489.8468 \\
\hline \hline
\end{tabular}

Normalized co-integrating coefficients (standard error in parentheses)

$\begin{array}{ccc}\text { PDRB } & \text { FIN } & \text { ZAKAT } \\ 1.000000 & 0.000000 & 1.265818 \\ & & (0.77336) \\ 0.000000 & 1.000000 & 0.175595 \\ & & (0.07993)\end{array}$

Adjustment coefficients (standard error in parentheses)

$\begin{array}{ccc}\mathrm{D}(\mathrm{PDRB}) & -0.002367 & 0.011495 \\ & (0.02939) & (0.15549) \\ \mathrm{D}(\mathrm{FIN}) & 0.078955 & -0.081021 \\ & (0.06737) & (0.35641) \\ \mathrm{D}(\text { ZAKAT }) & -16.67514 & -209.3525 \\ & (16.0661) & (85.0005)\end{array}$


Based on the results obtained, the probability value of more than $5 \%$ indicates that there is no co-integration. Thus, VAR is the appropriate model.

The next stage is to form a Vector Auto Regression Estimate to discover the variable relationships, while still allowing short-term dynamics. Using Wald test, this research found that Zakat has the short-run effect on financing in Islamic banking and gross regional economic growth, as the probability of Chi-Square test statistic is below $5 \%$.

Table 6. Wald Test Result

\begin{tabular}{lccc}
\hline \hline Test Statistic & Value & $\mathrm{df}$ & Probability \\
\hline \hline F-statistic & 3.127614 & $(2,21)$ & 0.0647 \\
Chi-square & 6.255227 & 2 & 0.0438 \\
\hline \hline
\end{tabular}

Null Hypothesis: $\mathrm{C}(12)=\mathrm{C}(13)=0$

Null Hypothesis Summary:

\begin{tabular}{lcc}
\hline \hline Normalized Restriction $(=0)$ & Value & Std. Err. \\
\hline \hline C $(12)$ & -0.000909 & 0.000664 \\
C $(13)$ & 0.044670 & 0.026321 \\
\hline \hline
\end{tabular}

Restrictions are linear in coefficients.

Moreover, using t-table value (2.0064), the following results are obtained which are presented in Table 7. According to the estimation result of VAR, it is found that the dependent variable on financing is significantly influenced by Zakat (-2). The estimated equation is presented as follows: $\mathrm{FIN}=\mathrm{C}(1,1) * \mathrm{FIN}(-1)+\mathrm{FIN}(-2)+\mathrm{C}(1,3) * \mathrm{PDRB}(-$ $1)+\mathrm{C}(1,4) * \operatorname{PDRB}(-2)+\mathrm{C}(1,5) * \mathrm{ZAKAT}(-1)$ $+\mathrm{C}(1,6) *$ ZAKAT $(-2)+\mathrm{C}(1,7)$

$\mathrm{PDRB}=\mathrm{C}(2,1) * \mathrm{FIN}(-1)+\mathrm{C}(2,2) * \mathrm{FIN}(-2)+$ $\mathrm{C}(2,3) * \operatorname{PDRB}(-1)+\mathrm{C}(2,4) * \operatorname{PDRB}(-2)+$ $\mathrm{C}(2,5) *$ ZAKAT $(-1)+\mathrm{C}(2,6) * \mathrm{ZAKAT}(-2)+$ $\mathrm{C}(2,7)$
With VAR Model - Substituted Coefficients: $0.799444598805 *$ FIN $(-1)$

$0.222554827937 * \mathrm{FIN}(-2)$

$0.429211679789 * \operatorname{PDRB}(-1)$

$0.516250867704 * \mathrm{PDRB}(-2)$

$0.00104244661642 *$ ZAKAT(-1)

$0.121879748377 *$ ZAKAT $(-2)$ 422.189283451

PDRB $=-0.163325084278 * \mathrm{FIN}(-1)+$

$0.212001981861 * \mathrm{FIN}(-2)$

$1.82817611253 * \operatorname{PDRB}(-1)$

$0.789398036693 * \operatorname{PDRB}(-2)$

$0.000810976956149 *$ ZAKAT( $(-1)$

$0.0411829977517 * Z$ AKAT(-2) -289.692102652

Table7. VAR Estimation Result

\begin{tabular}{|l|c|c|c|c|}
\hline $\begin{array}{c}\text { Dependent } \\
\text { Variable }\end{array}$ & $\begin{array}{c}\text { Independent } \\
\text { Variable }\end{array}$ & Coefficient & t-stats & Result \\
\hline FIN & FIN(-1) & 0.799445 & 4.44558 & Significant \\
\hline FIN & FIN(-2) & -0.222555 & -0.83912 & Not Significant \\
\hline FIN & PDRB(-1) & -0.429212 & -1.29626 & Not Significant \\
\hline FIN & PDRB(-2) & 0.516251 & 1.35692 & Not Significant \\
\hline FIN & ZAKAT(-1) & -0.001042 & -1.02867 & Not Significant \\
\hline FIN & ZAKAT(-2) & 0.121880 & 3.04723 & Significant \\
\hline FIN & Constanta & -422.1893 & -1.36497 & Not Significant \\
\hline PDRB & FIN(-1) & -0.163325 & -1.33825 & Not Significant \\
\hline PDRB & FIN(-2) & 0.212002 & 1.17780 & Not Significant \\
\hline PDRB & PDRB(-1) & 1.828176 & 8.13546 & Significant \\
\hline PDRB & PDRB(-2) & -0.789398 & -3.05727 & Significant \\
\hline
\end{tabular}




\begin{tabular}{|l|c|c|c|c|}
\hline PDRB & ZAKAT(-1) & -0.000811 & -1.17916 & Not Significant \\
\hline PDRB & ZAKAT(-2) & 0.041183 & 1.51717 & Not Significant \\
\hline PDRB & Constanta & -289.6921 & -1.38005 & Not Significant \\
\hline ZAKAT & FIN(-1) & -11.83937 & -0.29053 & Not Significant \\
\hline ZAKAT & FIN(-2) & -36.66695 & -0.61007 & Not Significant \\
\hline ZAKAT & PDRB(-1) & 45.80443 & 0.61044 & Not Significant \\
\hline ZAKAT & PDRB(-2) & -50.04770 & -0.58049 & Not Significant \\
\hline ZAKAT & ZAKAT(-1) & 0.848818 & 3.69616 & Significant \\
\hline ZAKAT & ZAKAT(-2) & -13.60388 & -1.50090 & Not Significant \\
\hline ZAKAT & Constanta & 104694.0 & 1.49366 & Not Significant \\
\hline
\end{tabular}

Impulse-Response Function (IRF) is used to track how fast a variable takes in responding to changes due to shocks from other variables. The resulting response may be positive, negative, or unresponsive, with horizontal charts close to the horizon line. Based on the IRF results, it is discovered that Zakat is affected when the disturbance variable (e) experiences shocks, by looking at the chart of "response of Zakat to Zakat", with its effect increasing over time. This is different from the effect on Zakat when purchasing power experiences shocks. The chart "response of Zakat to Fin" indicates that when purchasing power experiences shocks then the effect will continue to affect Zakat, with declining impact over time. In addition, significant reductions are also experienced by Zakat if shocks occur on economic growth (PDRB).

Figure 1. Impulse-Response Function Result
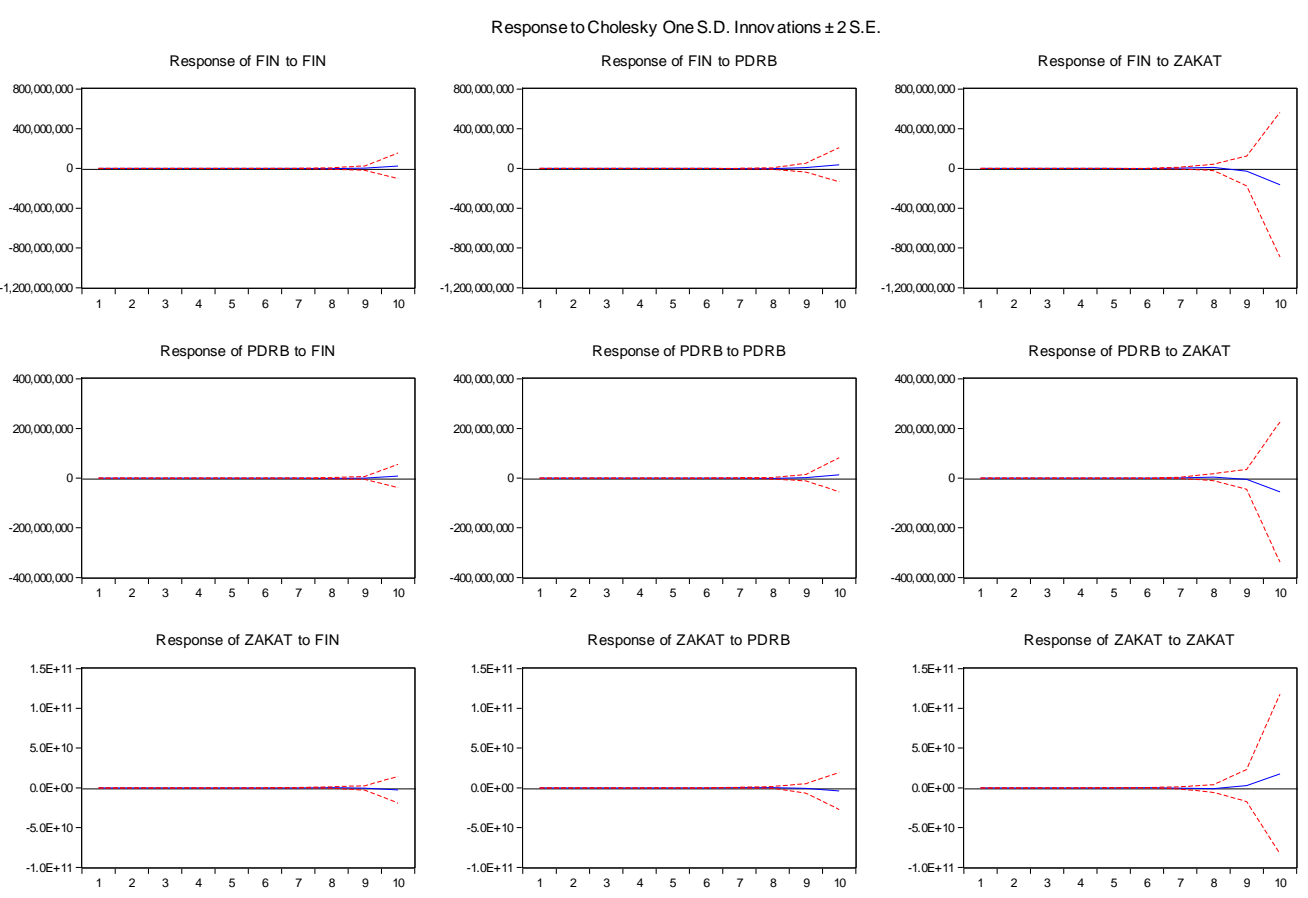

In the chart of "response of Fin to Zakat", the effect on Islamic bank's financing can be seen when Zakat experiences shock. The chart illustrates that when Zakat experiences shock, the effect will continue to affect the financing, with larger impact over time. This is different to the effect on financing when the disturbance variable (e) experiences shocks. The chart "response of Fin to Fin" shows that the effect will continue to affect Fin, with a small impact over time. The effect rises if shocks occur on economic growth (PDRB).

Meanwhile, the chart "response of PDRB to Zakat" is used to see the effect 
on PDRB when Zakat experienced shocks. The chart illustrates that when Zakat experiences shock, the effects will continue to affect the PDRB, with increasing effects over time. This is different from the effect on PDRB when Fin experiences shock. The chart of "response of PDRB to Fin" indicates that when PPP experiences shock, then the effect will continue to affect PDRB, but there will be a little impact over time. Same with the increase is due to shocks in the disturbance variable (e).

Thus, it can be concluded that the shocks occurring in Zakat receipts in West Java province will have a positive effect on the financing in Islamic banking and PDRB, with increasing impact over time.
This certainly adds a new research dimension, which previously did not put Zakat as a factor affecting economic growth in Indonesia. Among the important variables are consumption, investment, government spending (Ma'ruf \& Wihastuti, 2008), and net exports (Ernita, Amar, \& Syofyan, 2013). Furthermore, the Variance Decomposition (VD) analysis illustrates the relative importance of each variable due to shock. It is necessary to predict the percentage contribution of variants of each variable due to changes in a particular variable. Because VD results can provide information about the magnitude and duration of the shock from one variable to itself and from one variable to another variable.

Figure 2. Variance Decomposition Result
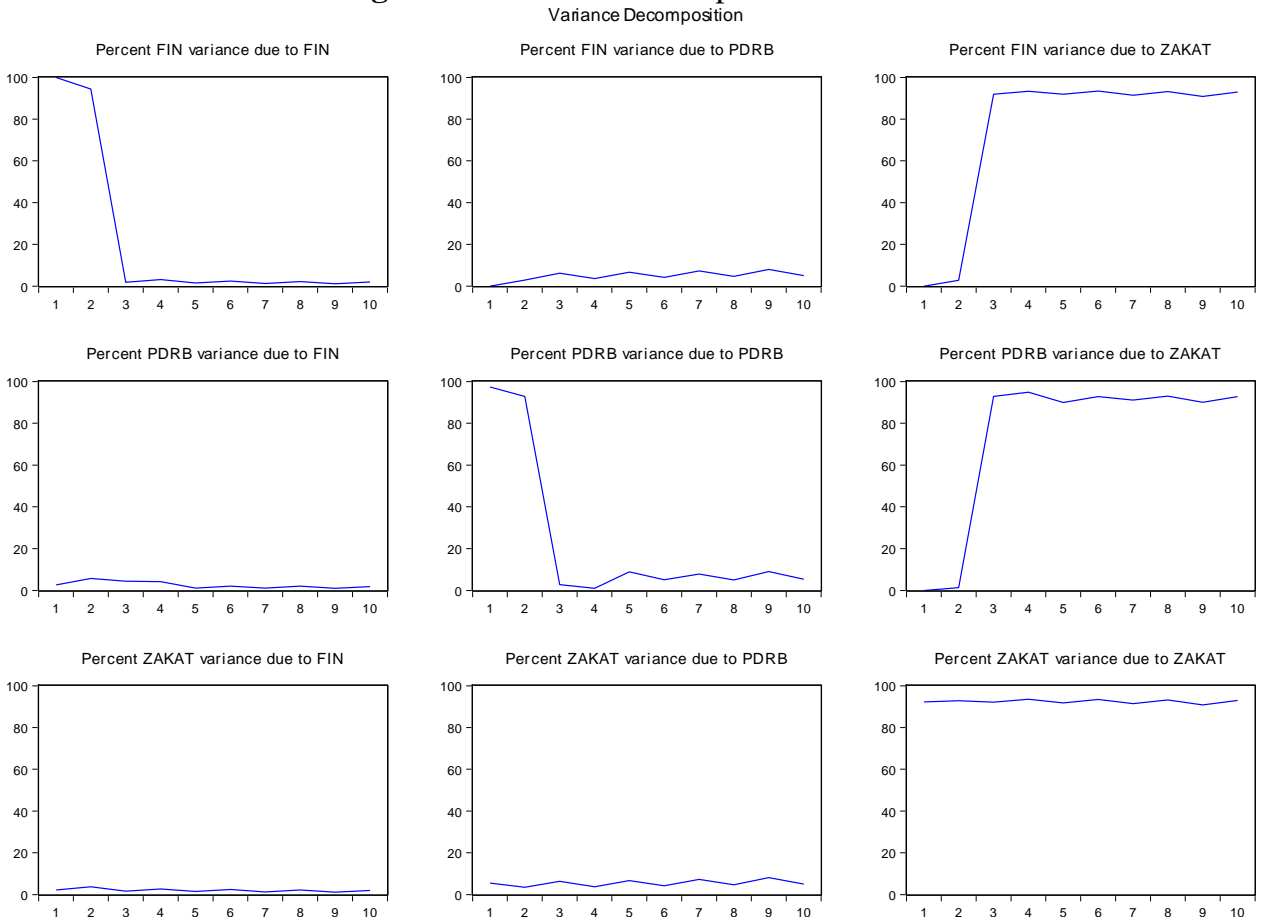

From the chart above, it can be seen that in the first period, Financing in Islamic Banking (FIN) is strongly influenced by shock on the variable financing itself. In that period, a shock from Zakat and regional economic growth (PDRB) does not give more influence yet. Furthermore, from period 2 to period 10, the proportion of Zakat shock to Financing is gradually increased by $90 \%$ till the end of the period, more than the shock from the regional growth.

Meanwhile, the shock effect of regional economic growth towards the new Zakat starts from the 3rd period, with an increasing contribution over the period up to $94.8 \%$. Meanwhile, shocks from financing (FIN) had a small contribution that fluctuated during the period with the highest influence in the 2 nd period by 
5.7\%. So, it can be concluded that the shock size of Zakat gives a greater influence on economic growth (PDRB) than the shock on financing (FIN).

However, it also shows that in the first period, Zakat is strongly influenced by shock on the variable Zakat itself. While in that period, shock from financing (FIN) and regional economic growth (PDRB) does not give more influence yet. Furthermore, from period 1 to period 10, the proportion of Zakat shock to Zakat itself is gradually fluctuating until the end of the period. Meanwhile, the shock effect of regional economic growth towards the new Zakat starts from the first period, with fluctuating contribution over the period by up to $8 \%$. Moreover, shocks from financing (FIN) has had a small contribution that fluctuated during the period with the highest influence in the 2nd period by $3.7 \%$. It can be concluded that the shock size of economic growth (PDRB) gives a greater influence on Zakat than the shock of financing (FIN). This is in line with Shiddiqi's theory that Zakat, which collected from the savings, income, and assets of Muslim communities which is a part of Zakat obligations, will, in the long run, contribute to the formation of national income with a positive relationship (Shiddiqi, 2005).

This result explains that Zakat has a central role in realizing social awareness and redistribution of income among Muslims. It also has an important value in the process of economic growth as a source of funds, as stated by Mth (2003).

The role of Zakat is not only limited to the local community. Despite agreeing on a positive role for government intervention in preparing for economic growth, we are yet to find a careful analysis of the relevant strategies and recommendations in this field.

The study of applications that examines the influence of Islamic values in the process of economic growth is almost non-existent in contemporary works. Material writings that often appear in the West reveal that Islamic values contradict economic growth. So Muslims are faced with a difficult choice between commitment to Islamic values or realizing the efforts of economic development.

The research of Bremer (2013) indicated that some have successfully applied the model in Egypt, such as Nasser Social Bank. In addition, this study also explains the need for Zakat reformation to liberate Zakat from traditional and static management models that dominate the practice of Zakat under state rules. As happened in America, Egypt and Indonesia, private Zakat collection and distribution programs are an urgent thing. This institution together with government institutions experimented with new models to utilize Zakat as a powerful Islamic finance tool to achieve an improvement of prosperity and reduction in poverty.

In relation to Zakat in Indonesia, other researchers using ethnographic fieldwork found that Zakat has undergone a role change from a religious obligation to a fundamental instrument for achieving social and economic justice (Retsikas, 2014). The success of the reconceptualizing of Zakat efforts depends on the political perspective of the government. Specifically, Rosadi \& Athoillah (2015) affirm that from the Indonesian point of view, decentralization is considered the best option in order for a region to collect funds which are returned to solve the problem of poverty in the area. Although historically, Abu Bakar once centralized Zakat to finance and mobilize the war to maintain the existence of religion ( $f i$ sabilillah), he also decentralized Zakat to achieve the goal of Shari'ah on Zakat.

This decentralization and its relation to how it can be tested by measures of economic growth, a research by Baskaran $\&$ Feld (2009) could be a reference. They examined the relationship between fiscal decentralization and economic growth in 23 OECD countries from 1975 to 2001 and 
discovered that fiscal decentralization and economic growth are unrelated.

On the other hand, high political temperatures in regional fiscal autonomy indicate a consistent negative signal indicating that it is important to separate politics and fiscal autonomy at the lowest government level when discussing the importance of decentralization or economic growth. It is because the fiscal decentralization is not relevant to the economic outcomes.

The aspect which the researchers find more relevant is related to the efforts to reduce income inequality. The research conducted by Cingano (2014) in the majority of OECD countries confirms that the gap between the rich and the poor is the highest since the last 30 years. Currently, the top $10 \%$ of the population in the OECD country has income which is 9.5 times of the $10 \%$ of the poorest. Even since the $1980 \mathrm{~s}$, the ratio is $7: 1$ and it continues to increase every year. However, this income inequality is not only related to the highest revenue sharing. Using the last 30-year data with econometric analysis indicates that tax-redistribution and transfer redistribution policies are a key tool for ensuring the benefits of growth being more widely distributed.

It is indeed interesting to analyze that what contributes to economic growth according to conventional theory. Lavoie \& Stockhammer (2012) explained that the growth model practice of Neoliberalism and Taxonomy of G20 countries shows that Indonesia is included in the strongly export-led model with China, Germany, Japan and South Korea. While Argentina, Brazil, Canada, Russia, and Saudi Arabia are in the weak export-led group. While France, Italy, India, South Africa, and Turkey are domestic demand-led. The rest of the countries, which are Australia, Mexico, Britain and United States, are including in the debt-led. However, according to Lavoie, the export-growth model was limited and triggered a global imbalance, while the debt-led model produced unsustainable consumption. Hence, alternatives such as a wage-led model that combines pro-labor distributional social and labor market policies become more appropriate to apply.

The theory of debt-led is also contentious among researchers. It can be seen from some research studies (Herndon, Ash, \& Pollin, 2013) which deny the statement 'Growth in Time of Debt' (Reinhart and Rogoff, 2010A and 2010B).

The mean and median economic growth is indicated by Gross Domestic Product (GDP). The public debt of more than $90 \%$ of GDP does not differ dramatically from when the ratio of public debt per GDP is smaller. The relationship between public debt and GDP growth varies significantly per period. In fact, this whole study refutes Reinhart and Rogoff's (RR) claim if the public debt / GDP ratio is above $90 \%$, it consistently reduces the GDP growth of a country.

In Indonesia, empirical facts forming economic growth also analyze the influence of determinants in the form of economic growth of the previous year, real government expenditure, real government budget deficit, degree of real economic openness, inflation, population, binary variable of natural resources and location and long-term decentralization dummy on economic growth in 26 provinces in Indonesia from 1980 to 2006 . The results show that the high convergence rates of Gross Regional Domestic Product in previous years, government expenditure, openness, natural resources, location and decentralization variables have a positive impact to increase economic growth. While the population with low labor force and inflation has a negative impact on economic growth (Ma'ruf \& Wihastuti, 2008).

Previous research (Jonaidi, 2012) in the 33 provinces in Indonesia for 20052009 shows that there is a strong two-way relationship between economic growth and poverty in Indonesia. Economic growth 
has a significant effect on the reduction of the poverty rate, especially in rural areas. Conversely, poverty has a significant effect on economic growth. With the same approach, (Ernita, Amar, \& Syofyan, 2013) explain that consumption, investment, government spending and net exports, partially and simultaneously, have a significant and positive impact on economic growth in Indonesia. Furthermore, (Lubis, 2013) describes the relationship between inflation and economic growth in Indonesia in 19682012 which negatively correlated by $4.3 \%$. The causality relationship takes place in one direction, namely the Gross Domestic Product (GDP) affecting the Consumer Price Index. However, there is a significant short and long-term relationship between inflation and economic growth.

The two-way relationship actually occurs in the financial sector. The Granger causality test shows that there is bidirectional causality between real output and loan volume and one-way causality from the spread to real output.

This VECM result tends to support that the financial system can become a growth engine in Indonesia (Inggrid, 2006). There is limited research on documenting the relation of the macro economy with Islamic social finance, especially Zakat. Among the research conducted previously, a research by Rusydiana (2009) used Vector Auto Regression (VAR) and Vector Error Correction Model (VECM) method which shows that the pattern of relationship between export and growth is bidirectional, i.e. growth driven export and export-led growth.

Another interesting finding is that the recent trend in Shari'ah industry has not positively correlated with macroeconomic growth. Moreover, it is well established that the greater growth of Indonesian economy is not accompanied by the increase in Shari'ah finance industry. So, it is needed to have a political will of the government so that the share of Shari'ah industry is able to grow and develop significantly.

This is in contrast to the study of panel data for the period of 2000-2009 in Malaysia, Indonesia and the Gulf Cooperation Council (GCC) which shows that Shari'ah banking contributes to economic growth in the short and long term, both in the Middle East and East Asian countries. In the short term, Shari'ah banks contribute more to economic growth in Malaysia and Indonesia than in the Middle East (GCC) countries (Yusof \& Bahlous, 2013).

\section{CONCLUSION}

Based on the analysis of VAR in this study, it is found that Zakat has an effect to boost financing in Islamic banking and economic growth in West Java, especially with a lag of two periods. The pattern of non-causal relationship means that it is not economic growth that encourages people to pay Zakat. On the contrary, based on the results of Granger causality test, it is identified that Zakat proved to be one of the determinants of financing in Islamic banking and economic growth (Zakat-led growth and financing hypothesis). Impulse Response Function (IRF) result also explains that the shocks occurring in Zakat revenue in West Java will have a positive effect on Financing in Islamic banking and regional economic growth (GDRP), with increasing impact over time.

The effectiveness of Zakat on financing and economic growth, by using variance decomposition analysis started to fluctuate from the second year. The amount of Zakat influenced variation in the financing by $2 \%$ on the lower side and $93 \%$ on the higher side. Likewise, it influenced economic growth by $1 \%$ to $94 \%$ on the lowest-highest range.

The results of this research are expected to be useful in recommending the Islamic banking industry and the 
regulators to continue promoting Zakat. This can be done through an increase in Zakat-raising efforts and the implementation of good governance for it, because of its significant impact on the development of Islamic banking and also the regional economic growth. Hence,

\section{REFERENCES}

Afrizal, F. (2013). Analisis Pengaruh Tingkat Investasi, Belanja Pemerintah dan Tenaga Kerja terhadap PDRB di Provinsi Sulawesi Selatan Tahun 20012011. Makassar: Universitas Hasanuddin.

Al-Haritsi, J. b. (2006). Fikih Ekonomi Umar bin Al-Khathab. (L. H. Asmuni Solihan Zamakhsyari, Trans.) Jakarta: Khalifa.

Ariyani, N. (2016). Zakat as a Sustainable and Effective Strategy for Poverty Alleviation: from the Perspective of a Multi-Dimensional analysis. International Journal of Zakat, 89107.

Azam, M., Iqbal, N., \& Tayyab, M. (2014). Zakat and Economic Development: Micro and Macro Level Evidence From Pakistan. Bulletin of Business and Economics, 3(2), 85-89.

Bank Indonesia. (2011). Statistik Perbankan Syariah. Jakarta: Direktorat Perbankan Syariah.

Bank Indonesia. (2012). Statistik Perbankan Syariah. Jakarta: Direktorat Perbankan Syariah.

Bank Indonesia. (2013). Statistik Perbankan Syariah. Jakarta: Direktorat Perbankan Syariah.

Bank Indonesia. (2014). Statistik Perbankan Syariah. Jakarta: Direktorat Perbankan Syariah.

Baskaran, T., \& Feld, L. P. (2009). Fiscal Decentralization and Economic Growth in OECD Countries: is going forward, this evaluation is also intended to be a consideration for other local governments, as well as Islamic financial practitioners to continue optimizing the potential of existing Zakat collection to reach more efficiency and greater impact. there a relationship? CESifo Working Paper No. 2721, 1-19.

Boeve, L. (2003). The Particularity of Religious Truth Claims: How to Deal with It in a So-Called PostModern Context. Leuven: Peeters.

BPS. ( 2016). Provinsi Jawa Barat Dalam Angka. Bandung: Badan Pusat Statistik Jawa Barat.

BPS. (2012). Provinsi Jawa Barat Dalam Angka. Bandung: Badan Pusat Statistik Provinsi Jawa Barat.

BPS. (2013). Provinsi Jawa Barat Dalam Angka. Bandung: Badan Pusat Statistik Provinsi Jawa Barat.

BPS. (2014). Provinsi Jawa Barat Dalam Angka. Bandung: Badan Pusat Statistik Provinsi Jawa Barat.

BPS. (2015). Provinsi Jawa Barat Dalam Angka. Bandung: Badan Pusat Statistik Provinsi Jawa Barat.

Bremer, J. (2013). Zakat and Economic Justice: Emerging International Models and their Relevance for Egypt. Third Annual Conference on Arab Philanthropy and Civic Engagement (pp. 51-74). Tunisia: Takaful.

Cingano, F. (2014). Trends in Income Inequality and Its Impact on Economic Growth. OECD Social, Employment and Migration Working Papers No.163.

Darwanis, M., \& Syukriy, A. (2013, Mei). Pengaruh Pendapatan Asli Daerah dan Dana Alokasi Umum terhadap Belanja Modal serta Dampaknya terhadap Pertumbuhan Ekonomi Daerah (Studi pada Kabupaten dan Kota di Aceh). Jurnal Akuntansi Pascasarjana Universitas Syiah Kuala, 2(2), 80-99. 
Dasuki, M. R. (2015). Teori Keadilan Sosial al-Ghazali dan John Rawls (Studi Perbandingan dalam Konteks Politik dan Hukum). Tangerang Selatan: Cinta Buku Media.

Ernita, D., Amar, S., \& Syofyan, E. (2013). Analisis Pertumbuhan Ekonomi, Investasi dan Konsumsi di Indonesia. Jurnal Kajian Ekonomi, 176-193.

Faisal. (2011). Sejarah Pengelolaan Zakat di Dunia Muslim dan Indonesia (Pendekatan Teori InvestigasiSejarah Charles Peirce dan Defisit Kebenaran Lieven Boeve). Analitis.

Freundenberg, B. (2011). The Constitution in Islam: Are Tax Reforms Possible to Facilitate Islamic Finance? Revenue Law Journal .

Ghadi, Y. M. (1994). Al-Amwal wa AlAmlak Al-'Ammah fi Al-Islam wa Al-Hukm Al-I'tida 'Alaiha. Baghdad: Mu'assah Ram.

Gujarati. (2004). Basic Econometrics. US: The McGraw-Hill Companies.

Hasan, Z. (2006). Sustainable Development from an Islamic Perspective: Meaning Implication and Policy Concerns. J.KAU: Islamic Econ, 19(1), 3-18.

Hassan, M. K., \& Khan, J. M. (2007). Zakat, External Debt and Poverty Reduction Strategy in Bangladesh. Journal of Economic Cooperation, $1-38$.

Herndon, T., Ash, M., \& Pollin, R. (2013). Does High Public Debt Consistenly Stifle Economic Growth? A critique of Reinhart and Rogoff. Cambridge Journal of Economics, $1-23$.

Inggrid. (2006). Sektor Keuangan dan Pertumbuhan Ekonomi di Indonesia: Pendekatan Kausalitas dalam Multivariate Vector Error Correction Model (VECM). Jurnal Manajemen dan Kewirausahaan, 40-50.
Jasafat. (2015, Juni). Manajemen Pengelolaan Zakat, Infaq dan Sadaqah pada Baitul Mal Aceh Besar. Jurnal Al-Ijtimaiyyah, 1(1), 1-18.

Jaya, I. P., \& Dwirandra, A. (2014). Pengaruh Pendapatan Asli Daerah pada Belanja Modal dengan Pertumbuhan Ekonomi sebagai Variabel Pemoderasi. E-Journal Akuntansi Universitas Udayana, 79-92.

Jonaidi, A. (2012). Analisis Pertumbuhan Ekonomi dan Kemiskinan di Indonesia. Jurnal Kajian Ekonomi, 140-164.

Kahf, M. (1997). Economics of Zakat: a book of Reading. Jeddah: IRTIIDB.

Kahf, M. (1999). The Performance of the Institution of Zakat in Theory and Practice. The International Conference in Islamic Economics Towards the 21st Century. Kuala Lumpur.

Kantakji, S. M. (2008). Dawabit AlIqtishad Al-Islami fi Mu'alijat AlAzmat Al-Maliyat Al-'Alamiyah. Damaskus: Dar Al-Nahdhah.

Keynes, J. M. (2003). The General Theory of Employment, Interest and Money. Gutenberg: Gutenberg of Australia eBook.

Lavoie, M., \& Stockhammer, E. (2012). Wage-led growth: Concept, Theories, and Policies. In Conditions of Work and Employment Series No.XX (pp. 142). Geneva: International Labour Office (ILO).

Lubis, I. F. (2013). Analisis Hubungan antara Inflasi dan Pertumbuhan Ekonomi: Kasus Indonesia. $Q E$ Journal, 41-52.

Mahat, N. I., \& Warokka, A. (2013). Investigation on Zakat as an Indicator for Moslem Countries' Economic Growth. J. Global Business Advancemenet, 6(1). 
Ma'ruf, A., \& Wihastuti, L. (2008). Pertumbuhan Ekonomi Indonesia: Determinan dan Prospeknya. Jurnal Ekonomi dan Studi Pembangunan, 44-55.

Misanam, M., \& dkk. (2008). Ekonomi Islam. Jakarta: Rajawali Press.

Mth, A. (2003). Konsep Pembangunan Ekonomi Islam. Al-Mawardi, $X$, 128-151.

Mustafa. (2014). Sistem Ekonomi Keuangan Publik Berbasis Zakat. Jurnal Madani, 28-42.

Nahi, S. '. (1994). Khawalid min Ara Abi Al-Hasan Al-Bashri Al-Baghdadi Al-Ma'ruf bi Al-Mawardi. Beirut: Dar Al-Jail.

OJK. (2015). Statistik Perbankan Syariah. Jakarta: Otoritas Jasa Keuangan.

Ramadhan. (2017). Kebijakan Publik dan Keadilan Sosial: Analisis terhadap Kitab al-Amwal al-Dawudi. Jakarta: UIN Jakarta.

Retsikas, K. (2014). Reconceptualising Zakat in Indonesia: Worship, Philanthropy and Rights. Indonesia and Malay World, 337-357.

Rosadi, A., \& Athoillah, M. A. (2015). Distribusi Zakat di Indonesia: antara Sentralisasi dan Desentralisasi. Ijtihad Jurnal Wacana Hukum Islam dan Kemanusiaan, 237-256.

Rusydiana, A. S. (2009). Hubungan antara Perdagangan Internasional, Pertumbuhan Ekonomi dan Perkembangan Industri Keuangan Syariah di Indonesia. TAZKIA Islamic Finance \& Business Review, 47-60.

Shiddiqi, M. N. (2005). Teaching Islamic Economics. Saudi Arabia: Scientific Publishing Center.

Sularno, F. M. (2013). Pengaruh

Pertumbuhan Ekonomi, Pendapatan Asli Daerah dan Dana Alokasi Umum terhadap Pengalokasian Anggaran Belanja Modal (Studi Kasus pada Kabupaten/Kota di Provinsi Jawa
Barat. Bandung: Universitas Widyatama.

Suprayitno, E., Kader, R. A., \& Harun, A. (2013, Jan-Mar). The Impact of Zakat on Aggregat Consumption. Journal of Islamic Economics, Banking and Finance, 9(1), 39-62.

Susanto, A. A., \& Cahyadin, M. (2008).

Praktik Ekonomi Islam di Indonesia dan Implikasinya terhadap Perekonomian. Jurnal Ekonomi Syariah MUAMALAH.

Winer, S. L., \& Hettich, W. (20004). Structure and Coherence in the Political Economy of Public Finance. Oxford Handbook of Political Economy, 1-2.

Yusof, R. M., \& Bahlous, M. (2013). Islamic Banking and Economic Growth in GCC \& East Asia Countries: A Panel cointegration analysis. Journal of Islamic Accounting and Business Research, 151-172.

Yussof, M. B. (2011, April). Zakat Expenditure, School Enrollment, and Economic Growth in Malaysia. International Journal of Business and Social Science, 2(6), 175-181.

Zulfa, A. (2013). Pengaruh Pendapatan Asli Daerah (PAD) dan Dana Alokasi Umum (DAU) terhadap Alokasi Belanja Daerah di Kabupaten Aceh Utara. Aceh Utara: Fakultas Ekonomi Universitas Malikussaleh.

Ai Nur Bayinah STEI SEBI Indonesia ai.nur.bayinah@sebi.ac.id 